\title{
THE COMMUNITY PERCEPTION TO GOOD GOVERNANCE IMPLEMENTATION OF VILLAGE FUNDS IN BANTUL REGENCY
}

\section{Gendro Wiyono $^{1}$, Fanda Susilawati ${ }^{2}$}

\author{
${ }^{1}$ Faculty Of Economics University Sarjanawiyata Tamansiswa Yogyakarta \\ ${ }^{2}$ Regional Revenue, Finance and Asset Management Service of Bantul Regency

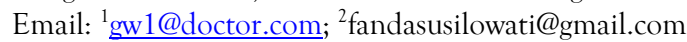

DOI: https://doi.org/10.18196/jgpp.5297

Article Info

Article history:

Received 22 Apr 2018

Revised 21 May 2018

Accepted 30 May 2018
Keywords:

Village Fund, Good Governance, Village Community Perception

\section{ABSTRACT}

This study aims to determine the perception of the community on the implementation of Village Fund Allocation that is used for the Implementation of Village Governance, Village Development, empowerment of rural communities, and Community Activities. with the influence of moderation good governance. The purpose of village fund allocation in principle to improve the welfare and equity of village development through improving public services in the village, promoting the village economy, overcoming the inter-village development gap and strengthening the village community as the subject of development. This is in accordance with the substance of Village Law No. 6/2014 to grant greater autonomy to the village in order to become self-reliant. currently there are still many parties who do not understand the use of village funds. There needs to be an appropriate and understandable media for village community can see and know the village government has done in the use of the village budget. This study uses secondary data collected from village administration, while primary data is collected from Bantul village community. Data analysis used Structural Equation Modeling based variance with the help SmartPLS software. The results showed that the simultaneous administration of village funding for all programs has a positive and significant impact on the perception of the village community perception, while the program partially for each funding does not significantly affect. Good governance as an independent variable significantly influences the perceptions of village communities, but the role of Governance for the implementation of each partial funding program has no significant effect on community village perception. 
ABSTRAK

Penelitian ini bertujuan untuk mengetahui persepsi masyarakat terhadap implementasi Alokasi Dana Desa yang diperuntukkan bagi Penyelenggaraan Pemerintahan Desa, Pembangunan Desa, Pemberdayaan Masyarakat, dan Kegiatan Kemasyarakatan, dengan pengaruh moderasi good governance. Tujuan alokasi dana desa pada prinsipnya untuk meningkatkan kesejahteraan dan pemerataan pembangunan desa guna mengatasi kesenjangan pembangunan antar desa serta memperkuat masyarakat desa sebagai subjek dari pembangunan. Hal ini sesuai dengan substansi dari Undang-Undang Desa No 6/2014 untuk memberikan otonomi yang lebih besar kepada desa agar dapat mandiri. Saat ini masih banyak pihak yang tidak memahami terhadap penggunaan anggaran dana desa. Perlu ada media yang tepat dan mudah dipahami agar masyarakat bisa melihat dan mengetahui apa yang telah dilakukan pemerintah desa dalam penggunaan anggaran desa. Penelitian ini menggunakan data sekunder yang dikumpulkan dari administrasi desa, sedangkan data primer dikumpulkan dari masyarakat desa Kabupaten Bantul. Alat analisis data yang digunakan Structural Equation Modeling berbasis variance dengan bantuan software SmartPLS. Hasil penelitian menunjukkan bahwa pelaksanaan alokasi dana desa secara simultan untuk semua program memiliki berpengaruh positif dan signifikan terhadap persepsi masyarakat desa, sedangkan program secara parsial untuk masing-masing pedanaan tidak berpengaruh signifikan. Tata kelola yang baik sebagai variabel independen berpengaruh secara signifikan terhadap persepsi masyarakat desa, tetapi peran Tata Kelola sebagai moderasi pelaksanaan setiap program pendanaan secara parsial tidak berpengaruh secara signifikan terhadap persepsi masyarakat.

\section{INTRODUCTION}

Changes in decentralized Indonesian governance in regional autonomy resulted in changes in the pattern of relationships between central and local governments (Salahudin: 2016). Decentralization is 
the transfer of authority of the central government to the autonomous regions to regulate and manage the affairs of government within the system of the Unitary State of the Republic of Indonesia. Theoretically, decentralization is expected to generate two tangible benefits: first, encouraging increased participation, initiative and creativity of the community in development, and encouraging equitable distribution of development outcomes across the region by utilizing resources and potentials available in local communities; second, able to improve the allocation of productive resources through shifting the role of public decision-making to the level of village governance (Mardiasmo: 2007, Kaho: 2010).

The purpose of the Village Fund allocation is principally to improve the welfare and equity of village development through improving public services in the village, promoting the village economy, addressing the inter-village development gap and strengthening the village community as the subject of development. This is in accordance with the substance of Village Law No. 6/2014 to grant greater autonomy to the village in order to become selfreliant. Law no. 6/2014 states that the village is a legal community entity which has territorial boundaries to govern his government affairs, the interests of local communities based on community initiatives, origins, and traditional rights recognized and respected within the system of state government unity of the Republic of Indonesia. The village as one of the elements of government that directly come into contact with the community becomes the main focus in government development. Thus, local governments are given broader autonomy in financing and managing regional development based on their own budgetary priorities (Salahudin: 2016). Based on this, it is hoped that there will be more open space for local authorities to formulate and implement development policies based on their own needs. Government Regulation No. 72/2005 on Village Article 68 paragraph 1 point c, states that part of the central and local 
214 balance funds received by the regency/municipalities for the village is at least $10 \%$ proportionally in the form of Village Fund Allocation. In order to improve the service and welfare of the community, the village has the right to obtain the share of local taxes and levies of regency/municipalities, as well as part of the central and regional financial balancing funds received by the regency. The acquisition of the village finance portion of the regency/municipalities hereinafter referred to as the village fund distributed through the village cash (Halim: 2012, Mardiasmo: 2007). Allocation of village funds is a manifestation of the fulfillment of the right of the village to organize its autonomy to grow and develop following the growth of the village itself based on diversity, participation, indigenous autonomy, democratization and community empowerment. The village fund is the allocation of funds to the village by calculation of the balancing funds received by the regency by $10 \%$ after deducting the Special Allocation Fund.

The legal basis for the allocation of balancing funds to the village in accordance with the mandate of Law Number 6/2014, if it is not enforced then strict sanctions stated that the government can make delays and/or deductions equal to the allocation of balance funds after deducting special allocation funds. In Government Regulation No. 43/2014 on the implementation of Law No. 6/2014 on villages, the allocation of village funds, based on the consideration of population size, poverty rate, geographical area and geographical difficulties. The objectives of village funds are: (1).To tackle poverty and reduce gaps; (2).Improving village level development planning and budgeting and community empowerment; (3).Increasing the development of rural infrastructure; (4).Enhancing the experience of religious, socio-cultural values in order to bring about social improvements in rural communities; (5).Increasing public order and tranquility; (6).To improve services to rural communities in the context of developing social and economic activities of the 
community; (7).Encouraging the improvement of self-help and community mutual cooperation; and (8).Increase the income of villages and villagers through village-owned enterprises. According to Hardi and Warsono (2014), the role of local government to realize the strategic autonomy of the village, both the original autonomy of the villages themselves and gained autonomy as a consequence of the decentralization principle. Village autonomy is native not a gift from the government. Instead the government is obliged to respect the customary autonomy of the village. Therefore, village funds should be arranged to the needs of the village community (Taufik: 2015).

The management of village funds in Bantul Regency has not been optimal yet and still faces obstacles that are not yet all mapped and resolved. The existing village government in Bantul regency, some have not developed and utilize the Village fund allocation in accordance with the principles of good government expected by the community. That is, in the implementation of village funds required training that gives the ability of the village administration to perform well and obey the principle. Indications of problems that arise include: (1).The distribution of the Village Fund still does not meet the operational standards and the needs of the village community, (2).The preparation of the Revenue and Expenditure Budget of the Village has not followed the process and stages as it should, (3).Proportion between unfair operational expenditures and development expenditures, (5).Financial Delivery Letters are often late.

\section{LITERATURE REVIEW}

\section{Village Fund}

The purpose of village funding in practice is not yet fully attainable due to the low quality of human resources, caused of the lack of education and the participation of the community in assisting the implementation of physical development (Ni Kadek et al: 2015, 
216 Nyimas: 2016). The presence of an independently administered village fund policy has a positive impact on village government. The presence of the village funds also gives the village government the freedom, development and social autonomy (Muhamad et al: 2017, Rasmah :2015, Luke and Ornsiri: 2009). In line with previous research, Fauzi et al (2013), Tjilen et al: (2016), asserted that village funds have the effect of: (1).Increasing the delivery of government services in implementing development; (2).Improving village institutions in the planning, implementation and control of development and community participation; (3).Increase the income, employment and opportunities of village communities in the framework of socio-economic development of the community; (4).Encourage community participation with non-government.

In order for the village funds to achieve its objectives, it needs to be done with the principle of good governance. According to Hendi (2017), good governance implies the activities of a government institution run on the interests of the people and the norms that apply to realize the ideals of the country. Good governance is a solid and responsible management of development in line with efficient democratic and market principles, avoids misallocation of funds, prevents corruption both politically and administratively, conducts budgetary discipline and creates legal and political frameworks for business growth (LAN- BPKP: 2000). Conceptionally, the implementation of good governance in the management and utilization of village funds in accordance with the allocation so as to be able to overcome the problems that exist in the village. However, if viewed from the development that has been running for this, the implementation of good governance in Indonesia has not been fully successful. There is still much cheating and leakage in the management of the budget and accounting (Titiek and Yulianto: 2016). 


\section{Good governance}

Good governance demonstrates a process whereby people can manage their economies, institutions and social and political resources not only for development, but also to create cohesion, integration, and for the welfare of the people. The ability of the state to achieve its goals depends largely on the quality of governance and interaction with the private and public sectors (Thoha: 2017). Good Governance does not merely involve the government and state, but also the role of various actors outside government and state so that the parties involved are also very wide (Dayanandan: 2013, Young et al.: 2011). In the governance management structure, there are three pillars of governance, namely: government, private sector, and society, so that the mechanism of management of economic and social resources involving the influence of state and non-government sectors in a collective activity (Santosa: 2008).

In order for the village government to have good quality in financial accountability, good implementation of village financial management should be done (Yuswandi: 2016). Richardo (2014) research results, cooperation has been established well, cooperation has been mutually supportive, it's just a problem occurs because not all activities can be informed to the public so that the news that makes people look negative. In the meantime, Syofian and Tiyas (2014) research concludes the lack of village cooperation on the grounds that lack of coaching and training impacts the ability of village government apparatus. Result of research of Titiek and Yulianto (2016) and Rani (2015) provide a similar statement that the obstacles to the implementation of good governance of village financial management due to human resources in the village government are not competent. In line with Sarintan's (2016) study concluded that the field that is still very far from the implementation of regional autonomy and a serious concern and should be addressed to encourage policy makers to implement in accordance with existing 
218 regulations and empower the community and village government to be more familiar with the role and function. According to Sanusi (2014), village funds have implications for encouraging change or improving village development. Although the implementation has not been effective yet the management has shown a significant change to the welfare of the community. Although in the process faced with administrative problems, but the accumulative management of the allocation of village funds reached the target is very clear that can improve and improve the village development. However, the implementation still faces problems related to the disbursement of funds that are not always synchronized with the planned activities caused by the lack of funds and the limited skilled and experienced personnel, as well as the mentality of village officials who lack discipline in working.

United Nations Development Program (UNDP: 2011), states "governance is defined as the exercise of political, economic, and administrative authority to manage a nation's affairs". Governance is defined as the exercise of political, economic and administrative authority to manage the affairs of the nation. Governance is a complex institution, mechanism, process and relationship as a way for citizens and groups to articulate their interests, exercise their rights and obligations, and mediate or facilitate differences between them (Widodo: 2008). Understanding of governance put forward by UNDP, according to the State Administration Institution (2000) has three legs of economic, political, and administrative. Economic governance includes decision-making processes that affect the economic activity of the country or relate to other economies, either directly or indirectly. Economic governance has an influence or implication on equity, poverty, and quality of life. Political governance refers to the process of decision making and the implementation of a legitimate and authoritative state/government policy. 
Continue the explanation above, indicator of good governance according to UNDP (2011) as follows: (1).Participation: every citizen has a voice in decision making, either directly or intermediation legitimacy institution represents its importance. Such participation is built on the basis of the legitimacy of association and of speaking and participating constructively. (2).Rule of law: the legal framework should be fair and undertaken indiscriminately, especially the law for human rights. (3).Transparency: transparency is built on the validity of information flows. Processes, institutions and information that are directly acceptable to those in need. (4).Responsive: Institutions and processes should serve every stakeholder. (5).Consensus Orientation: good governance mediates different interests to get the best option for broader interests, both in procedural policy. (6).Equity; All citizens, both men and women have the opportunity to improve and maintain their welfare. (7).Effectiveness and effeciency: processes and institutions produce according to what has been outlined by using the best available resources. (8).Accountability: decision-makers in government, the private sector and society are accountable to the public and stakeholder institutions. (9).Strategic vision: leaders and the public should have good governance and development perspectives that are broad and far ahead in line with what is required for development. Implementation of all good governance indicators, required as a requirement for the creation of good governance and clean governance. In implementing the indicators above, then one of the necessary in order to realize good governance is the creativity of leaders in carrying out their functions or roles, through a democratic leadership pattern that always creates synergies among various elements of development optimally.

\section{Perception}

The management of village funds is not only sufficient with training but also needs mentoring, as mandated by Law No. 6/2014, the central government, provincial and regency/municipal 
221 governments empower villagers by: (1).Applying the results of science development knowledge and technology, appropriate technology; (2).New findings for economic and agricultural progress of rural communities; (3).Improving the quality of government and village communities through education, training; (4).Recognize and enable the existing institutions in the village community. Village community empowerment is implemented with assistance in the planning, implementation and monitoring of village and rural development. That is, the government is obliged to provide guidance to the village in order to empower the village community, management of village funds, so that it can be used properly targeted according to the needs of village development.

The guidance of the village community as stated in Government Regulation No. 43/2014 is clarified and affirmed as follows: (1).Government and local government organize the empowerment of rural community with the assistance in stages in accordance with the needs; (2).The technical assistance by the regency/municipal apparatus can be assisted by professional assistants, village community empowerment cadres, or third parties; (3). Sub-District Head or the assistance of village communities. The professional auxiliaries are: (1).The personnel in charge of assisting the village in the administration of the village administration, village cooperation, the development of village-owned enterprises, and the local village-scale development; (2).Technical assistants assigned to assist the implementation of sectoral programs and activities; and (3).Community empowerment experts who are tasked with increasing the capacity of assistants in the implementation of village governance, village development implementation, village community development, and empowerment of rural communities.

As the objectives of the implementation of village funds described above, certainly in reality will be observed the people who see, hear, and feel that lead to the formation of perceptions among 
the community. Perception is one of the important psychological aspects for humans in responding to the presence of various aspects and symptoms around it. Perception contains a very broad sense, concerning the internal and external. Experts have given a diverse definition of perception, although in principle it has the same meaning. Perception includes all signals in the nervous system, which are the result of physical or chemical stimulation of the sensory organs. The process of knowing a few things through the five senses. Mahmud (2017) suggests that perception is the ability of the brain in translating the stimulus or the process to translate the stimulus into the human sense device.

Perceptions According to Salahudin (2016) is the observation of objects, events or relationships obtained by concluding information and interpreting messages. Robert et al. (2010) states: "perception is a process of interpreting or interpreting information obtained through the system of the human senses". According to him there are three aspects in the perception that are considered relevant to human cognition, namely: the recording of the senses, pattern recognition, and attention. From the explanation can be drawn a common opinion that perception is a process that begins from the vision to form a response that occurs within the individual so that the individual is aware of everything in the environment through the senses it has. In relation to the problem of perception, Hildah and Nyovani's (2014) stated that village goverment should understand the factors that influence village development according to the village people's point of view. Therefore it is necessary to know the multidimensionality of development perceived by the community. It requires non-specific and contextual action to understand and plan policies that focus on the anticipated perceptions, needs, and development outcomes based on individual and socio-economic characteristics of rural communities. As the result of research conducted by Sitti (2013) that people's perception have different 
222 response to the result of service of village government. Based on the above theoretical explanation, the research model developed as follows.

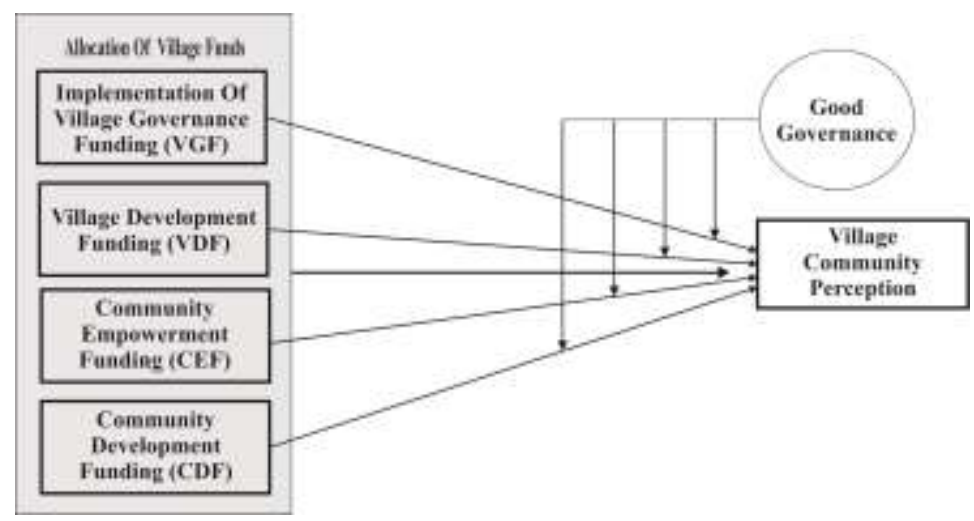

Figure 1: Research Model

The research framework in Figure-1 above is a concise form to explain the relationship between variables that theoretically allegedly interact with each other. Regulation of the Minister of Home Affairs No. 114/2014 article 3 says that village development as referred to in Article 2 covers the areas of village government administration, the implementation of village development, the development of rural communities and the empowerment of rural communities. According to Ahmad et al (2017), perceptions of village government apparatus and the community towards the use of funds for the implementation of village administration show a good interpretation is indicated by the percentage value of the perception given of $71.8 \%$. The perceptions of village development activities, community empowerment activities, and community activities show excellent interpretation. This is indicated by the percentage of perceptions given respectively $88,6 \% ; 85.4 \%$; and $81.2 \%$. The study was supported by Heppy et al. (2018) and Feiby et al (2018) who claimed that the Village Fund had a significant effect on infrastructure development. As for the community empowerment and participation, Dahyar (2017) research result stated that the implementation of 
Village Fund Program has a positive and significant impact on the participation level of the villagers. Community participation starts from planning, implementation, to the preservation of the results of village development both in the form of giving advice, assistance of goods, energy, and participate in utilizing the results of development in the village.

From the results of this study, the higher the village funds the greater the influence on the village development. However, the implementation of village funds requires assistance as stipulated in Government Regulation No. 43/2014 that the Government and local governments to organize the empowerment of village communities with assistance in stages in accordance with needs. It is interpreted in this case that with assistance the implementation of village funds will run in accordance with expectations. In order for the village funds to achieve its objectives, it needs to be done with the principle of good governance. According Sadjijono (2007) good governance means the activities of a government agency run on the interests of the people and the norms that apply to realize the ideals of the country. Good governance is a solid and responsible management of development management in line with efficient democratic and market principles, avoiding misallocation of funds, preventing corruption both politically and administratively, exercising budget discipline and creating legal and political frameworks for business growth. Conceptionally, the implementation of good governance in the management and utilization of village funds in accordance with the allocation so as to be able to overcome the problems that exist in the village.

However, the implementation of village funds that have been described above in reality will be observed people who see, hear, and feel that lead to the formation of perceptions among the community. According to Mahmud (2017), perception is the ability of the brain in translating the stimulus or the process to translate the stimulus that 
221 goes into the human senses. Bimo (2015) reveals that perception is the process of organizing, interpreting the stimulus received by organisms or individuals so that it becomes something meaningful, and is an integrated activity within the individual. Meanwhile, Robert et al. (2010) states that perception is the process of interpreting information obtained through the system of the human sense device, namely: sensory recording, pattern recognition, and attention. That is, perception is a process that starts from the vision to form a response that occurs in the individual so that the individual is aware of everything in the environment through the senses he has. Thus how the implementation of village funds with the mentoring process based on good governance will shape the perception for the community.

Based on the above theories and studies, the hypothesis developed as follows:

H1. The village funds for village administration has a positive and significant impact on public perception.

H2. The village funds for village development has a positive and significant impact on public perception.

H3. The village funds for the community empowerment has a positive and significant impact on public perception.

H4. The village funds for community activities has a positive and significant impact on community perceptions.

H5. Implementation of good governance has a positive and significant impact on public perception.

H6. Simultaneously the use of village funds for: the implementation of village governance, village development, village community empowerment, and community activities have a positive and significant impact on public perception.

H7. Implementation of good governance in the implementation of village governance has a positive and significant impact on public perception. 
H8. The implementation of good governance in village development has a positive and significant impact on public perception.

H9. Implementation of good governance in the empowerment of village communities have a positive and significant impact on public perception.

H10. The implementation of good governance in village community activities has a positive and significant impact on public perception.

\section{RESEARCH METHOD}

This research is done by quantitative method. The population of the study included the community and village government apparatus. The unit of analysis of this study are individuals who understand the substance of research obtained as a sample by using purposive sampling technique. By using such techniques it is expected that the data obtained will be relevant to the research problem. Data were collected by documentation method for secondary data, while primary was obtained by using questionnaire.

Table 1: Data, Methods, and Data Sources

\begin{tabular}{|c|c|c|c|}
\hline Data needs & $\begin{array}{l}\text { Data } \\
\text { types }\end{array}$ & Method & Data source \\
\hline $\begin{array}{l}\text { Village Government } \\
\text { Budget } 2015\end{array}$ & Secondary & Documentation & $\begin{array}{c}\text { Regional } \\
\text { Revenue, } \\
\text { Finance and } \\
\text { Asset } \\
\text { Management } \\
\text { Service of } \\
\text { Bantul } \\
\text { Regency }\end{array}$ \\
\hline $\begin{array}{l}\text { 1. Implementation } \\
\text { Of Village } \\
\text { Governance }\end{array}$ & Secondary & Documentation & $\begin{array}{c}\text { Regional } \\
\text { Revenue, } \\
\text { Finance and }\end{array}$ \\
\hline
\end{tabular}




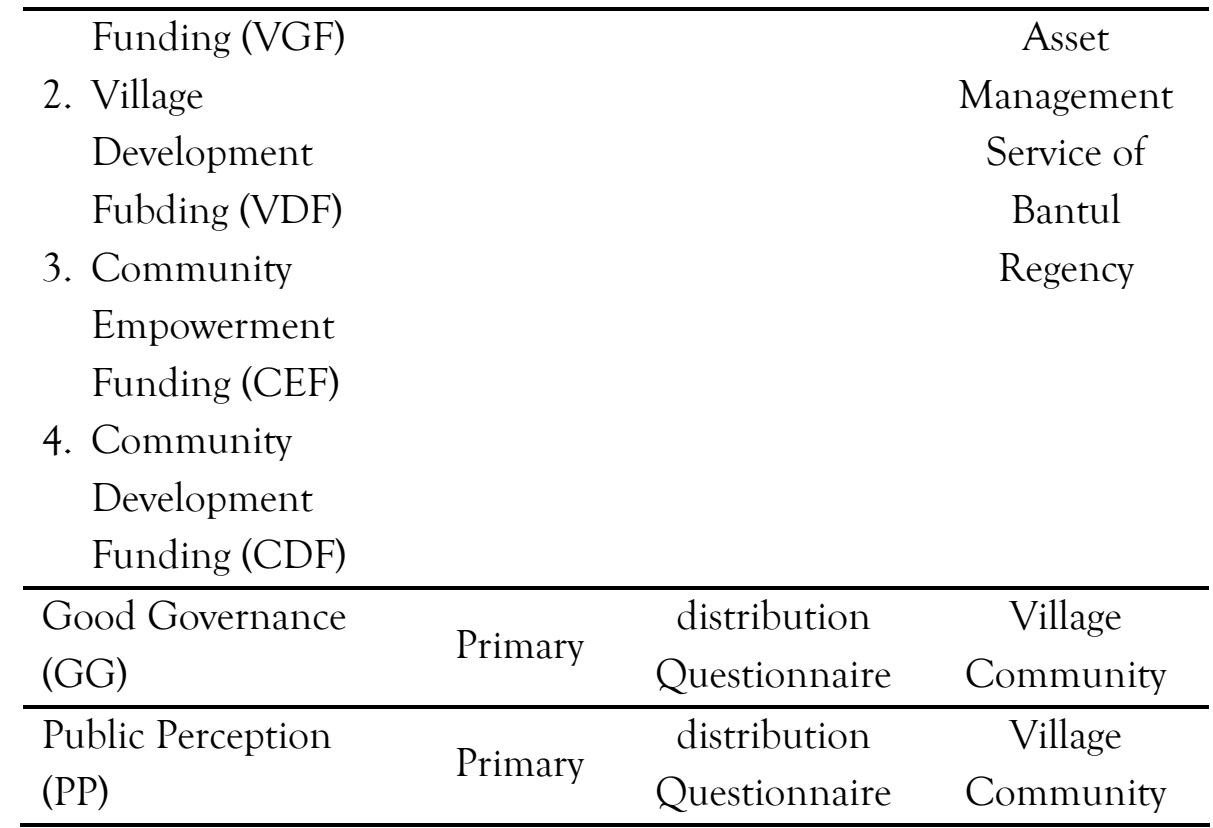

This research model uses two latent variables with operational definition as shown in the following table.

Table 2: Operational Definitions

\begin{tabular}{|c|c|c|}
\hline No. & latent Variable & Indicator \\
\hline 1 & $\begin{array}{l}\text { Good governance } \\
\text { (UNDP, 2011) }\end{array}$ & $\begin{array}{l}\text { a. Participation: Are communities } \\
\text { being involved in decision-making } \\
\text { and participation in village } \\
\text { development. } \\
\text { b. Rule of law: Is the implementation } \\
\text { of village funds have applied the law } \\
\text { fairly. } \\
\text { c. Transparency: Whether the village } \\
\text { government is already open in the } \\
\text { village fund information and } \\
\text { accountability. } \\
\text { d. responsive:Whether the village } \\
\text { government have served the people } \\
\text { well } \\
\text { e. Consensus Orientation: Whether } \\
\text { the village government in making } \\
\text { policies and procedures already }\end{array}$ \\
\hline
\end{tabular}




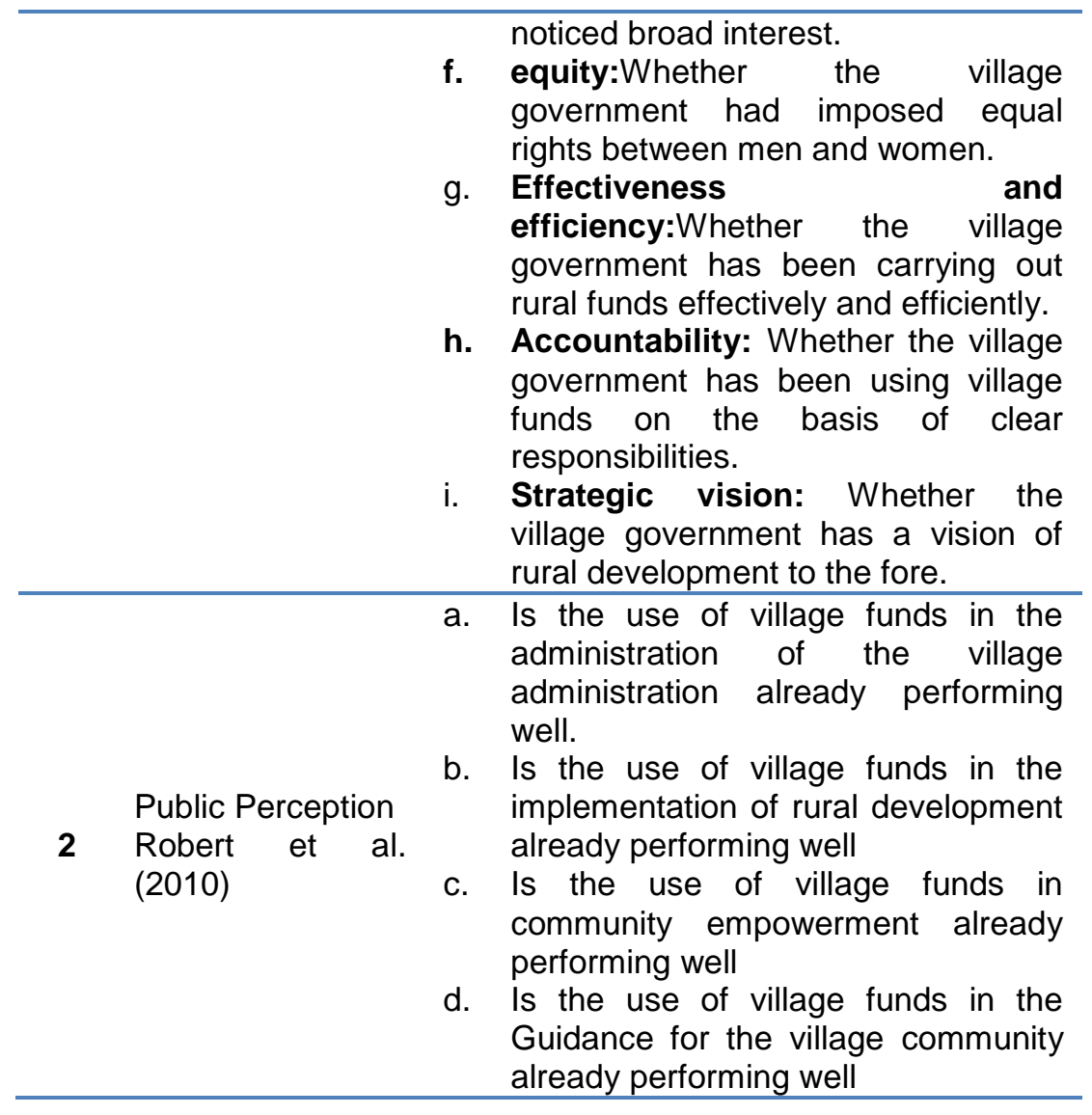

Data analysis was performed using SmartPLS ver. 3.2.7. The initial stage of this SmartPLS model is to perform the Measurement Model, which is to test the relationship between the indicators of the construct variables (Wiyono: 2011). If the measurement model is accepted it can be continued to the inner model that is a structural model that illustrates the influence between variables based on substantive theory. Inner model is a test of the structural model is done by looking at the value of $\mathrm{R}^{2}$ as a test of goodness of fit model (Wiyono: 2011). Besides, there is also significance test of influence between construct by looking at coefficient value of parameter and Pvalue value. 


\section{RESULTS AND DISCUSSION \\ Charasteristic Respondents}

characteristic of respondents used as samples in this study in the following table:.

Table 3: Description of Respondents

\begin{tabular}{|c|c|c|c|c|c|}
\hline \multirow{2}{*}{1} & \multirow{2}{*}{ Gender } & \multicolumn{2}{|c|}{ Man } & \multicolumn{2}{|c|}{ woman } \\
\hline & & \multicolumn{2}{|c|}{$71(47.33 \%)$} & \multicolumn{2}{|c|}{79 (52.67\%) } \\
\hline \multirow[b]{2}{*}{2} & \multirow[b]{2}{*}{ Education } & High School & D3 & $\mathrm{S} 1$ & S2 \\
\hline & & $\begin{array}{c}98 \\
(65.33 \%)\end{array}$ & $\begin{array}{c}15 \\
(10 \%)\end{array}$ & $\begin{array}{c}34 \\
(22.67 \%)\end{array}$ & $\begin{array}{c}3 \\
(2 \%)\end{array}$ \\
\hline \multirow{2}{*}{3} & \multirow{2}{*}{ Work } & Entrepreneur & $\begin{array}{l}\text { College } \\
\text { student }\end{array}$ & farmer & more \\
\hline & & $\begin{array}{c}8 \\
(5.33 \%)\end{array}$ & $\begin{array}{c}24 \\
(16 \%)\end{array}$ & $\begin{array}{c}27 \\
(18 \%)\end{array}$ & $\begin{array}{c}0 \\
(0 \%)\end{array}$ \\
\hline
\end{tabular}

\section{Measurement Model}

The first phase of the research is a test of the validity and reliability of the indicators that shows how strong the results of the use of theoretical measurements used to define the construct (Hair et al: 2013). The strong correlation between construct and indicator and its relation to other variables is one way to test the validity of constructs, which consists of convergent validity, discriminant validity, and composite reliability. Test results as shown in the table below.

Table 4: Convergent Validity

\begin{tabular}{lcc}
\hline \multicolumn{1}{c}{ Model } & Loading & Status \\
\hline $\mathrm{Y} 1 \rightarrow \mathrm{PP}$ & .773 & valid \\
$\mathrm{Y} 2 \rightarrow \mathrm{PP}$ & .765 & valid \\
$\mathrm{Y} 3 \rightarrow \mathrm{PP}$ & .743 & valid \\
$\mathrm{Y} 4 \rightarrow \mathrm{PP}$ & .777 & valid \\
$\mathrm{Z} 2.1 \rightarrow \mathrm{GG}$ & .700 & valid \\
$\mathrm{Z} 2.2 \rightarrow \mathrm{GG}$ & .682 & valid \\
$\mathrm{Z} 2.3 \rightarrow \mathrm{GG}$ & .826 & valid \\
$\mathrm{Z} 2.4 \rightarrow \mathrm{GG}$ & .655 & valid \\
$\mathrm{Z} 2.5 \rightarrow \mathrm{GG}$ & .775 & valid \\
$\mathrm{Z} 2.6 \rightarrow \mathrm{GG}$ & .317 & Invalid \\
$\mathrm{Z} 2.7 \rightarrow \mathrm{GG}$ & .338 & Invalid \\
$\mathrm{Z} 2.8 \rightarrow \mathrm{GG}$ & .350 & Invalid \\
$\mathrm{Z} 2.9 \rightarrow \mathrm{GG}$ & .437 & Invalid \\
\hline
\end{tabular}


Based on table- 4 above there is a valid construct due to $>.600$, but some are invalid because $<.600$

\begin{tabular}{cccc}
\multicolumn{4}{c}{ Table 5: Discriminant Validity } \\
\cline { 1 - 3 } Indicator & \multicolumn{2}{c}{ Latent variables } & Status \\
\cline { 2 - 3 } & GG & Perception & \\
\hline Y1 & .395 & .773 & valid \\
Y2 & .365 & .765 & valid \\
Y3 & .294 & .743 & valid \\
Y4 & .453 & .777 & valid \\
Z 1 & .700 & .337 & valid \\
Z 2 & .682 & .343 & valid \\
Z 3 & .826 & .427 & valid \\
Z 4 & .565 & .232 & valid \\
Z 5 & .775 & .408 & valid \\
Z 6 & .317 & .077 & valid \\
Z 7 & .338 & .158 & valid \\
Z 8 & .350 & .237 & valid \\
Z 9 & .437 & .223 & valid \\
\hline composite & .808 & .849 & reliable \\
Reliability & & & \\
\hline
\end{tabular}

Discriminant validity indicate that all indicators are valid with strong correlation results with the parent construct compared to other constructs. Besides that the test also shows reliable with result of .849 $>.700$.

\section{Inner Model}

Model after the measurement test as shown in above Figure 2 below. 


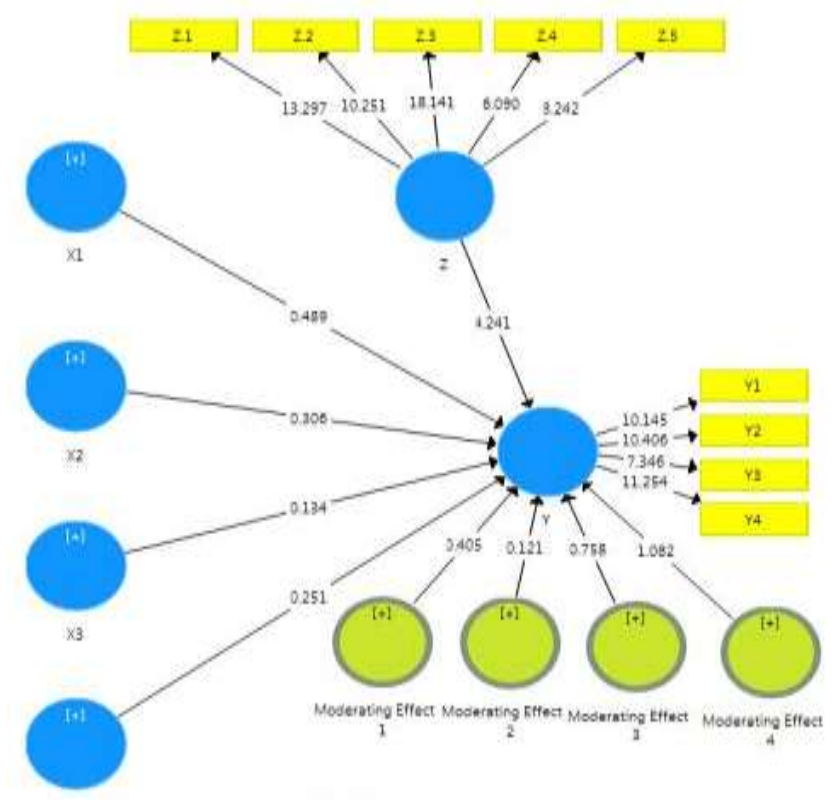

Figure-2: Model Test Results

The result of the model test, as stated in table- 6 .

Table 6: Testing Hypotheses

\begin{tabular}{cccc}
\hline & Original & & \\
Hypothesis & Sample & & \\
& (Coefficient & $\mathrm{P}_{\text {value }}$ & Result \\
& Parameters) & & \\
\hline
\end{tabular}

H1. The village funds for village administration has a positive and significant impact on $.099 \quad .646 \quad$ Rejected public perception.

H2. The village funds for village development has a positive and significant impact on public $\begin{array}{lll}.054 \quad .077 \quad \text { Rejected } & \end{array}$ perception. 
H3. The village funds for the community empowerment has a positive and significant impact on public perception.

H4. The village funds for community activities has a positive and significant impact $.063 \quad .799$ Rejected on community perceptions.

H5. Implementation of good governance has a positive and significant impact on public $.543 \quad .000 \quad$ Accepted perception.

H6. Simultaneously the use of village funds for: the implementation of village governance, village development, village community empowerment, and community activities have a positive and significant impact on public perception.

H7. Implementation of good governance in the implementation of village governance has a positive and $\begin{array}{lll}-.028 & .812 \quad \text { Rejected }\end{array}$ significant impact on public perception.

H8. The implementation of good governance in village development has a positive and significant impact on public $\begin{array}{rll}-.051 \quad .615 \quad \text { Rejected } & \end{array}$ perception 


$232 \begin{aligned} & \text { H9. Implementation of good } \\ & \text { governance in the } \\ & \text { empowerment of village }\end{aligned}$
$\begin{aligned} & \text { communities have a positive } \\ & \text { and significant impact on }\end{aligned}$
$\begin{aligned} & \text { public perception. } \\ & \text { H10. The implementation of good }\end{aligned}$
governance in village
community activities has a .260
positive and significant impact
on public perception

The results of goodness of fit is shown by $\mathrm{R}^{2}$ (Wiyono: 2011) of .263 with $\mathrm{P}_{\text {value }}=.005$ which means simultaneously all activities funded by village funds have positive and significant impact on community perception (H6). This supports previous research by Helen (2014), Rasmah (2015) , and Lukas and Ornsiri (2009), which asserted that the presence of village funds was able to provide the village government's freedom, development and social social autonomy. In line with this, Fauzi Asni et al (2013), Tjilen et al. (2016), Muhammad et al. (2017) affirms that village funds have the effect of: (1). Improving the implementation of government services in implementing development; (2).Increasing the village institutions in the planning, implementation and control of development and community participation; (3).Increasing the income, employment and opportunities of village communities in the framework of socioeconomic development of the community; and (4).Encouraging community participation with non-government. While the program partially has no significant effect on public perception. The purpose of the village funds in practice is not yet fully achievable because of the low quality of human resources, which is motivated by the lack of 
education and the participation of the community in assisting the physical development of development (Ni Kadek et al: 2015, Nyimas: 2016).

Good governance as an independent variable actually has a significant effect on the perception of the community, but for the implementation of each program partially does not significant effect on community perception. This is in line with the results of observations LAN and BPKP (2000) that from the development that has been running so far, the implementation of good governance in Indonesia has not been fully successful. There is still a lot of cheating and leakage found in the management of budget and accounting (Titiek and Yulianto: 2016). Richardo's (2014) and Hardi and Warsono (2014) results also find the same findings that accountability of village funds to communities has not been good. Meanwhile, Syofian and Tiyas (2014) research concludes the lack of village cooperation on the grounds that lack of coaching and training affects the ability of village government apparatus. The research results of Titiek and Yulianto (2016), and Rani (2015) provide a similar statement that the obstacles to the implementation of good governance of village financial management are due to inadequate human resources in village government.

The management of the village fund in Bantul Regency has not been running optimally yet still faces some obstacles that can not be mapped and resolved yet. The many village governments in Bantul regency, some have not developed and utilize the Village Fund in accordance with the principles of good government expected by the community. That is, in the implementation of the implementation of village funds is still needed training and coaching to improve the ability of the village administration to perform well and obey the principle. Indications of problems that arise include: (1). The allocation of Village Funds Funds still does not meet the operational standards and needs of the villagers, (2).The preparation of the 
23. revenue and expenditure budget of the village has not followed the process and stages as it should, (3).Income accounts and wrong account codes, (4).Proportions between uneven operational expenditures and development expenditures, (5).Financial report is often late.

The above problems are perceptions that are known and understood by society. According to Hildah and Nyovani (2014) stated that village goverments should understand the factors that influence village development according to the village people's point of view. Therefore it is necessary to know the multidimensionality of development perceived by the community. It requires non-specific and contextual measures to understand and plan policies focused on the anticipated per-sons, needs, and development outcomes based on individual and socio-economic characteristics of rural communities, it should be understood that community perceptions have different responses to village government service outcomes Sitti: 2013).

\section{CONCLUSIONS}

This study resulted in goodness of fit shown by R2 equal to .263 with $\mathrm{P}_{\text {value }}=.005$ meaning that simultaneously all activity funded by village fund have positive and significant influence to village community perception. This means that overall activities funded by the village funds are perceived positively by the community. Nevertheless, the program partially has no significant effect on village community perception. Good governance as a stand-alone variable actually has a significant effect on the perception of village community, which means that the implementation of good governance is perceived by the community. However, for the implementation of each program is not perceived partially by the community, meaning that the role of good governance as a moderation effect has no positive effect on the perception of the community, so it needs to be reevaluated and enhanced its role. The managerial implication of this research that the implementation of village funds need to get assistance so that it can be realized in accordance with the objectives to be achieved. 


\section{REFERENCES}

Ahmad Soleh, Feri Susanto, Reka Susanti. (2017). Persepsi Aparatur

Pemerintah Desa Terhadap Dana Desa Di Kecamatan Seluma Barat

Kabupaten Seluma. Ekombis Review Program Studi Akuntansi Fakultas

Ekonomi Universitas Dehasen Bengkulu. Hal. 114-125

Bimo (2015). Pengantar Psikologi Umum. Yogyakarta: Andi Offset.

Dahyar, Daraba. (2017). Pengaruh Program Dana Desa Terhadap Tingkat Partisipasi Masyarakat Di Kecamatan Galesong Utara Kabupaten

Takalar. Sosiohumaniora, Volume 19 No. 1 Maret 2017 Hal: 52 - 58

Dayanandan (2013). Good Governance Practice for Better Performance of Community Organizations Myths and Realities!!. Journal of Power, Politics \& Governance, Vol. 1 No.1, December 2013.

Fauzi, Asni. Maryunani, Sasongko. Dwi, Budi .(2013). The Management of the Village Fund Allocation as an Instrument towards Economic Independence Village (Case Studies in 2 villages in Siak Regency, Province Riau). IOSR Journal of Business and Management (IOSRJBM)e-ISSN: 2278-487X, p-ISSN: 2319-7668. Volume 10, Issue 4 (May. - Jun. 2013), PP 01-09. www.iosrjournals.org

Feiby, Vencentia T. Vicky V. Panelewen. Arie D. P. (2018). Dampak Program Dana Desa Terhadap Peningkatan Pembangunan Dan Ekonomi Di Kecamatan Pineleng Kabupaten Minahasa. AgriSosioekonomiunsrat,Issn 1907-4298, Volume 13 Nomor 2a, Juli $2017: 335-342$

Hair, J.F. et al. (2013). Multivariate data analysis 7th ed., Pearson Education Limited.

Halim, Abdul. (2012). Manajemen Keuangan Daerah. Yogyakarta: UPP STIM YKPN

Hardi, Warsono. Ruksamin. (2014). The Obstacles of Implementation of Village Allocation Fund Program in the North Konawe Southeast Sulawesi. Journal of Management and Sustainability; Vol. 4, No. 3; 2014 ISSN 1925-4725 E-ISSN 1925-4733.

Helen, Florensi. (2014). Pelaksanaan Kebijakan Alokasi Dana Desa dalam M emberdayakan Masyarakat Desa di Desa Cerme, Kecamatan Grogol, Kabupaten Kediri. Kebijakan dan Manajemen Publik ISSN 2303 - 341X Volume 2, Nomor 1, Januari 2014.

Hendi, Sandi Putra. (2017). Tata Kelola Pemerintahan Desa Dalam Mewujudkan Good Governance Di Desa Kalibelo Kabupaten Kediri. Jurnal Politik Muda, Vol. 6, No. 2, April-Juli 2017, 110 - 119 
Heppy, Purbasari. Bramudya, Wisnu W. Ilham, Adhi P. (2018). Analisis Pengaruh Pendapatan Asli Desa, Dana Desa, Alokasi Dana Desa Dan Bagi Hasil Pajak Dan Retribusi Terhadap Belanja Desa Bidang Pekerjaan Umum Dan Pertanian (Studi Empiris Di Seluruh Desa Se-Kabupaten Sukoharjo). The $7^{\text {th }}$ University Research Colloqium 2018 Stikes Pku Muhammadiyah Surakarta

Hildah, Essendi. Nyovani, Madise. (2014). Factors Influencing Perception Of Development In Rural Kenya: A Structural Equation Modeling Approach. European Journal of Research in Social Sciences Vol. 2 No. 4, 2014 ISSN 2056-5429.

Kaho, Josef R. (2010). Prospek Otonomi Daerah di Negara Republik Indonesia : Identifikasi Faktor-Faktor yang mempengaruhi Penyelenggaraan Otonomi Daerah. Jakarta : PT. Rajawali Pers.

LAN-BPKP, (2000), Akuntabilitas dan Good Governance, Jakarta:LAN-RI. Modul 1-5, Modul Sosialisasi Sistem Akuntabilitas Kinerja Instansi Pemerintah (AKIP), LAN BPKP RI, Jakarta.

Lukas, Menkhoff . Ornsiri, Rungruxsirivorn. (2009). Village Funds and Access to Finance in Rural Thailand. Discussion Paper No. 417.

Mahmud, Dimyati (2017). Psikologi Pendidikan. Yogyakarta: Widya Ananda Mardiasmo. (2007), Otonomi Daerah dan Manajemen Keuangan Daerah. Yogyakarta : Andi Offset

Muhammad Eko Atmojo. Helen Dian Fridayani, Aulia Nur Kasiwi, Mardha Adhi Pratama. (2017). Efektivitas dana desa untuk pengembangan potensi ekonomi berbasis partisipasi masyarakat di Desa Bangunjiwo. Jurnal Sosial Politik Humaniora. http://journal.umpo.ac.id lindex.php/aristo/aristo@umpo.ac.id. P.126-140.

Ni Kadek Darmiasih. Ni Luh Gd Erni Sulindawati. Nyoman Ari Surya Darmawan. (2015). Analisis Mekanisme Penyaluran Alokasi Dana Desa Pada Pemerintahan Desa (Studi Kasus Desa Tri Buana, Kec.Sidemen, Kab.Karangasem). e-Journal S1 Ak Universitas Pendidikan Ganesha Jurusan Akuntansi Program S1 (Volume 1 No: 3 Tahun 2015.

Nyimas Latifah Letty Aziz. (2016). The Village Autonomy And The Effektiveness Of Village Fund.. Jurnal Penelitian Politik / Volume 13 No. 2 Desember 2016 / 193-211.

Peraturan Pemerintah 72 Tahun 2005 tentang Desa

Peraturan Pemerintah Nomor 43 Tahun 2014 tentang peraturan pelaksanaan Undang-Undang Nomor 6 Tahun 2014 tentang desa 
Rani Eka Diansari . (2015). Analisa Implementasi Alokasi Dana Desa Kasus Seluruh Desa di Kecamatan Kledung Kabupaten Temanggung. Seminar Nasional Universitas PGRI Yogyakarta 2015.

Rasmah, Hasman. (2015). Implementasi Kebijakan Alokasi Dana Desa Di Kecamatan Kinovaro Kabupaten Sigi. e-Jurnal Katalogis, Volume 3 Nomor 11, Nopember 2015 hlm 107-117 ISSN: 2302-2019 Hal. 107117.

Richardo Juniaster Tampubolon. (2014). Pelaksanaan Prinsip Good Governance Dalam Alokasi Dana Desa Di Desa Teluk Bakau Kecamatan Gunung Kijang Kabupaten Bintan Tahun 2013. Unpublish Manuscript.

Robert L. Solso, Otto H. Maclin , M. Kimberly Maclin S. (2010). Psikologi Kognitif. Yogyakarta: Erlangga.

Salahudin, Anas. (2016). Filsafat Pendidikan, cet. ke-10. Bandung: Pustaka Setia, 2011

Santosa, Pandji. (2012). Administrasi Publik, Teori dan Aplikasi Good Governance. Bandung:Refika Aditama.

Sanusi. DB.Paranoan. Achmad Djumlani. (2014). Implementasi Kebijakan Alokasi Dana Desa Di Desa Balansiku Kecamatan Sebatik. elournal Administrative Reform, 2014, 2 (3): 1732-1745 ISSN 2338-7637, ar.mian. fisip-unmul.ac.id.

Sarintan Efratani Damanik. (2016). Pemberdayaan Desa Untuk Penguatan Partisipasi Masyarakat Dalam Penyelenggaraan Pemerintahan Desa. www.usi.ac.id/karya ilmiah dosen.

Sitti Rusnani. (2013). Persepsi Masyarakat Tentang Pelayanan Publik Di Kantor Kelurahan Handil Bakti Kecamatan Palaran Kota Samarindah. elournal Administrasi Negara, 2013 , 1 (2): 365-379 ISSN 00000000, ejournal.an.fisip-unmul.org.

Syofian dan M.Y. Tiyas Tinov. (2014). Transformasi Pelaksanaan Pemerintahan Desa. Jurnal Kebijakan Publik, Volume 5, Nomor 1, Maret.

Taufik Kurrohman. (2015). Accountability of planning on village fund allocation in osing community in Banyuwangi. Department of Accounting, University of Jember, Indonesia International Conference on Accounting Studies (ICAS) 2015 17-20 August 2015, Johor Bahru, Johor, Malaysia.

Thoha, Miftah. (2017). Dinamika IImu Administrasi Publik. Yogyakarta: Prenada Media Group 
Titiek Puji Astuti. Yulianto. (2016). Good Governance Pengelolaan Keuangan Desa Menyongsong Berlakunya Undang-Undang No. 6 Tahun 2014. Berkala Akuntansi dan Keuangan Indonesia 1 (2016): 1-14.

Tjilen, Alexander Phuk. Frans Papilaya and Edi Cahyono. (2016). Implementation of the Economic Program Empowerment of Local Communities in Sota District, Merauke Sub District. Review Pub Administration Manag, an open access journal ISSN: 23157844Volume $4 \cdot$ Issue $3 \cdot 1000195$.

Village Law No. 6/2014 (Undang-Undang Nomor 6 Tahun 2014 Tentang Desa)

Government Regulation No. 72/2005 on Allocation Village Fund (UndangUndang Nomor 72 Tahun 2005 Tentang Alokasi Dana Desa)

UNDP. (2011). Governance Principles, Institutional Capacity And Quality.

Widodo. (2008), Good Governance Telaah Dari Dimensi Akuntabilitas, Kontrol Birokrasi Pada Era Desentralisasi Dan Otonomi Daerah, Surabaya : Insan Cendekia.

Wiyono, Gendro. (2011). Merancang Penelitian Bisnis, Dengan Alat Analisis SPSS 17.0 \& Smart PLS 2.0. Yogyakarta: UPP STIM YKPN.

Young Sokphea, Soparth Pongquan. Sophal Ear. (2011). Local Good Governance of Rural Infrastructure Development Planning: Case Studies of Commune Councils in Cambodia. IJERD - International Journal of Environmental and Rural Development (2011) 2-1.

Yuswandi A. Temenggung. (2016). Rural Financial Management in Perspective Law N0.6 of 2014 Concerning The Village. International Journal Of Social Sciences ISSN 2305-4557. 